\title{
REVIEW AKTIVITAS FARMAKOLOGI TANAMAN KANGKUNG HUTAN (Ipomoea carnea Jacq)
}

\author{
Nova Rahma Widyaningrum ${ }^{1}$, Andriani Noerlita Ningrum ${ }^{2}$, Siti Maesaroh ${ }^{3}$ \\ STIKES Mamba'ul Ulum Surakarta \\ thussannofx@gmail.com
}

\begin{abstract}
ABSTRAK
Latar Belakang: Kangkung hutan (Ipomea carnea Jacq) mengandung zat aktif berupa flavonoid, polifenol dan alkaloid, yang diduga memiliki kemampuan sebagai analgetik, antioksidan, antikanker, antimikroba, antiinflamasi dan penyembuh luka sayat. Belum banyak pemanfaatan tanaman kangkung hutan, sebagian besar hanya dibiarkan saja tumbuh di ladang atau area persawahan atau menjadi pakan ternak saja. Hal ini dirasa perlu dilakukan kajian literatur mengenai berbagai aktivitas farmakologi dari tanaman kangkung hutan, terlebih pada masa pandemi ini, aktivitas penelitian preklinis terbatas.

Tujuan penelitian: Mengkaji aktivitas farmakologi Ipomea carnea Jacq berdasarkan kandungan fitokimianya.

Metode: Penelitian dilakukan dengan kajian literature review analisis deskriptif dari berbagai jurnal penelitian tunggal. Penelusuran artikel dilakukan dengan menggunakan database Researchgate, Scholars Research Library, Elsevier dan Juniper. Penelusuran dilakukan dengan menggunakan kombinasi kata kunci aktivitas farmakologi dan skrining fitokimia tanaman kangkung hutan menggunakan penghubung "dan/and" baik berbahasa Inggris maupun Indonesia. Penelusuran disesuaikan dengan kriteria inklusi kemudian diskrining berdasarkan judul dan abstrak untuk mengeliminasi artikel yang tidak sesuai.

Hasil: Proses penyarian kangkung hutan dilakukan dengan menggunakan metode maserasi, sokhletasi dan refluk. Penyari yang digunakan juga bervariasi, antara lain etanol, etil asetat, kloroform dan air, kemudian beberapa jurnal melakukan fraksinasi dari pelarut utamanya. Bagian tanaman yang digunakan sebagian besar adalah daun dan bunga, tetapi ada juga yang menggunakan akar untuk uji farmakologinya. Hasil skrining fitokimia dan uji kualitatif, tanaman kangkung hutan mengandung senyawa aktif flavonoid, senyawa fenolik, tanin, saponin, terpenoid, sterol dan alkaloid.

Simpulan: Tanaman kangkung hutan memiliki beberapa aktivitas farmakologi yang direview dan bermanfaat bagi pemeliharaan kesehatan, antara lain sebagai penyembuh luka sayat, antimikroba, antiinflamasi, analgetik, antioksidan dan antikanker
\end{abstract}

Kata Kunci: kangkung hutan, aktivitas farmakologi, literatur review 


\begin{abstract}
Background: Kangkung hutan (Ipomea carnea Jacq) contains active substances like flavonoids, polyphenols and alkaloids. This plant are thought having pharmacological avtivites as an analgesic, antioxidant,anticancer, antiinflammatory, antimicrobacterial and wound healing. But in fact, its still useless for medication, most of them are only left to grow in fields or become animal feed. It is deemed necessary to conduct a literature review regarding the various pharmacological activities of Ipomea carnea, especially during this pandemic, preclinical research activities are limited.

Research purposes: To review pharmacology activites from Ipomea carnea according to its active compounds.

Methods: The study was conducted with a literature review and descriptive analysis of various single research journals. The search for articles was carried out using the Researchgate database, Scholars Research Library, Elsevier and Juniper. This searching was carried out using a keyword combination of pharmacological activity and phytochemical screening of kangkung hutan using the link "dan/and" in both English and Indonesian. This searching was adjusted for inclusion criteria were then screened by title and abstract to eliminate nonconforming articles.
\end{abstract}

Results: The process of extracting Ipomea carnea was carried out using maceration, sokhletation and reflux methods. The solvents were used also varied, including ethanol, ethyl acetate, chloroform and water, then several journals also used fractionation method from the main solvent. Most of the plant parts used are leaves and flowers, but there also used roots for pharmacological tests. The results of phytochemical screening and qualitative tests showed that kangkung hutan contains active flavonoids, phenolic compounds, tannins, saponins, terpenoids, sterols and alkaloids.

Conclusion: Ipomea carnea had some activities pharmacology according to the journal review, that could be usefull for mantaining our health like wound healing, antimicrobial, anti-inflammatory, analgesic, antioxidant and anticancer properties

Keywords: Ipomea carnea, pharmacology activites, literature review

\title{
PENDAHULUAN
}

Saat ini minat masyarakat untuk memanfaatkan kembali obat yang berasal dari alam sangat besar. Hal ini dikarenakan efek sampingnya relatif kecil atau bahkan tidak ada bila dibandingkan dengan obat yang berasal dari bahan sintetis. Banyak jenis tumbuhan yang telah diteliti, dan terbukti memiliki efek yang berkhasiat sebagai tanaman obat dan dijadikan untuk alternatif pengobatan. Salah satunya adalah tanaman kangkung hutan (Ipomea carnea Jacq).

Tanaman kangkung hutan ini adalah salah satu tanaman yang memiliki racun untuk binatang ternak. Racun terletak pada biji, dimana banyak mengandung 
selenium dengan kadar tinggi. Racun ini dapat menyebabkan depresi, tremor, gugup, kurus karena terjadi kegagalan saluran pencernaan, dll (Sharma and Bacheeti, 2013). Selain kandungan seleniumnya, tanaman kangkung hutan juga memiliki kandungan senyawa aktif golongan fenolik, yang terakumulasi pada bunga (konsentrasi fenolik paling besar) dan batang (konsentrasi fenolik paling rendah). Sedangkan kandungan flavonoid, khususnya katekol dan kuersetin tersebar pada bunga, daun dan batang (Khatiwora, et al, 2010). Senyawa fenol ini berkhasiat sebagai antioksidan juga sebagai imunomodulator, sedangkan flavonoid memiliki khasiat sebagai antibakteri, antiinflamasi, antialergi serta antikanker (Khatiwora, et al, 2010; Adsul, et al, 2012; Khalid, et al, 2011; dan Deshpande, et al, 2012). Kandungan lain pada tanaman kangkung hutan ini antara lain saponin, xanthoprotein, triterpenoid dan tannin (Sharma and Bacheeti, 2013).

Pemanfaatan daun kangkung hutan belum cukup optimal, hal ini dikarenakan minimnya pengetahuan masyarakat tentang manfaat besarnya. Daun kangkung hutan diduga memiliki kemampuan sebagai antiinflamasi, maka diduga pula mampu memiliki kemampuan antipiretik (Khalid, et al, 2011). Flavonoid yang terkandung pada daun kangkung hutan merupakan senyawa terbesar dari fenol, yang bekerja dengan menghambat pertumbuhan bakteri serta menghambat prostaglandin akibat adanya pirogen (Moot, et al, 2013). Kandungan flavonoid pada daun kangkung hutan diduga bekerja dengan menghambat enzim siklooksigenase, yaitu enzim yang muncul saat peradangan atau infeksi jasad renik, sehingga dapat menurunkan prostaglandin. Hal ini akan berakibat meningkatkan vasodilatasi di kulit, sehingga pengeluaran kalor akan meningkat disertai dengan meningkat pula pengeluaran keringat (Wilmana, 2007).

Belum banyak pemanfaatan tanaman kangkung hutan, sebagian besar hanya dibiarkan saja tumbuh di ladang atau area persawahan atau menjadi pakan ternak saja. Hal ini dirasa perlu dilakukan kajian literatur mengenai aktivitas-aktivitas farmakologi dari tanaman kangkung hutan, sehingga masyarakat dapat memanfaatkan tanaman tersebut untuk pengobatan juga dapat berhati-hati terhadap aktivitas tanaman tersebut sebagai racun karena tingginya kadar seleniumnya. Hal inilah yang membuat peneliti tertarik untuk mengkaji aktivitas farmakologi dari tanaman kangkung hutan yang kurang dikenal masyarakat menggunakan metode kajian literatur jurnal berdasarkan kandungan senyawa kimia yang dimilikinya.

\section{METODE}

Penelusuran artikel penelitian tunggal dilakukan dengan menggunakan database Researchgate, Scholars Research Library, Elsevier dan Juniper. Setiap penelusuran di database, digunakan beberapa model kata kunci yang sama, antara lain: (1) kangkung hutan/Ipomea carnea Jacq, (2) aktivitas farmakologi, (3) aktivitas fitokimia. Kata kunci tersebut dikombinasi baik dengan bahasa Indonesia maupun bahasa Inggris dengan menggunakan penghubung "DAN/AND". Strategi penelusuran tidak dibatasi tahun publikasi, tetapi dipilih jenis fulltext dan tidak berbayar serta berbahasa Inggris dan Indonesia. 
Kriteria inklusi dalam penelusuran jurnal ini adalah : (1) artikel adalah berjenis penelitian tunggal baik berbahasa Indonesia maupun bahasa Inggris, (2) membahas tentang aktivitas farmakologi dari kangkung hutan dengan berbagai metode pengujian, (3) membahas tentang fitokimia dan senyawa aktif yang terkandung dalam kangkung hutan, (4) artikel yang dipublikasikan pada rentang tahun 2005 - 2020, dengan metode random sampling pada pengujiannya baik hewan uji maupun tanamannya.

Kriteria ekslusi dalam penelusuran jurnal ini antara lain : 1) artikel yang tidak membahas tentang aktivitas farmakologi untuk manusia, 2) artikel yang berisi kumpulan abstrak saja, dan 3) artikel tidak terduplikasi pada publikasi di database yang digunakan. Penelusuran disesuaikan dengan kriteria inklusi kemudian diskrining berdasarkan judul dan abstrak untuk mengeliminasi artikel yang tidak sesuai.

Langkah terakhir adalah proses ekstraksi atau pengelompokkan perolehan data artikel riset disajikan berdasarkan tahun publikasi, judul yang sesuai, nama penulis, bagian tanaman yang digunakan, aktivitas farmakologi yang diteliti, metode yang digunakan, senyawa kimia yang terkandung dan dilakukan pengujian aktivitas, serta hasil penelitian tunggal terhadap tanaman kangkung hutan.

\section{HASIL DAN PEMBAHASAN}

\section{Hasil}

Pada penelitian ini diperoleh 26 hasil penelitian mengenai tanaman kangkung hutan, baik pada manusia maupun pada insekta. Hasil pencarian kemudian disaring dengan membaca judul secara cepat, ketersediaan abstrak dan fulltext diperoleh 18 artikel. Kemudian dilakukan telaah dan kesesuaian kriteria inklusi dan ekslusi diperoleh artikel sebanyak 9, sedangkan 1 artikel duplikasi sehingga yang dianalisis hanya 7 artikel.

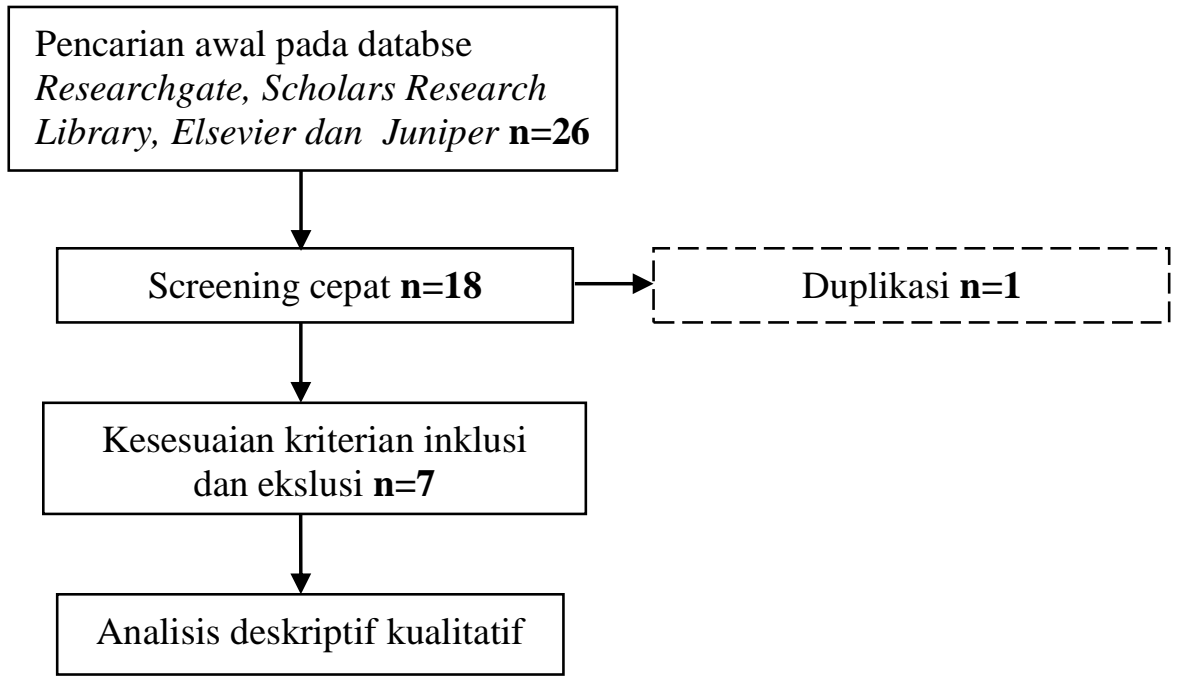

Gambar 2. Penelusuran Literatur 
Hasil pencarian ini kemudian dilakukan ekstraksi data artikel, yang berisi gambaran umum artikel seperti tahun publikasi, penulis, judul penelitian, teknik sampling, bagian tanaman yang diuji, senyawa yang diuji, aktivitas farmakologi dan hasil penelitian dari artikel tersebut. Hasil ekstraksi dapat dilihat pada tabel di bawah ini:

Tabel 1. Ekstraksi Data Artikel Penelitian

\begin{tabular}{|c|c|c|c|c|c|}
\hline $\begin{array}{c}\text { Peneliti/ } \\
\text { Tahun }\end{array}$ & Judul & $\begin{array}{c}\text { Aktivitas } \\
\text { Farmakologi }\end{array}$ & $\begin{array}{c}\text { Bagian } \\
\text { Tanaman }\end{array}$ & $\begin{array}{c}\text { Senyawa } \\
\text { Kimia }\end{array}$ & Temuan Utama \\
\hline $\begin{array}{l}\text { Ambiga } \\
\text { S, et al, } \\
2007\end{array}$ & $\begin{array}{l}\text { Evaluation of } \\
\text { Wound } \\
\text { Healing } \\
\text { Activity of } \\
\text { Flavonoids }\end{array}$ & $\begin{array}{l}\text { Mengeringka } \\
\text { n luka sayat }\end{array}$ & $\begin{array}{c}\text { Bunga } \\
\text { kangkung } \\
\text { hutan }\end{array}$ & flavonoid & $\begin{array}{l}\text { Isolasi kandungan senyawa } \\
\text { flavonoid pada bunga } \\
\text { kangkung hutan menggunakan } \\
\text { etanol 95\% melalui refluk, } \\
\text { kemudian difraksinasi dengan } \\
\text { dietil eter, kloroform dan } \\
\text { etilasetat. Uji aktivitas terhadap } \\
\text { luka sayat dilakukan } \\
\text { menggunakan tikus ras Wistar, } \\
\text { parameter yang dilihat } \\
\text { histopatologi dan kecepatan } \\
\text { kesembuhan luka sayatan. } \\
\text { Ekstrak bunga kangkung hutan } \\
\text { memiliki aktivitas penyembuh } \\
\text { luka dibandingkan dengan } \\
\text { kontrol positif Sulfatiazole. }\end{array}$ \\
\hline $\begin{array}{l}\text { Adsul } \\
\text { VB., et } \\
\text { al, } 2012\end{array}$ & $\begin{array}{l}\text { Antimicrobial } \\
\text { activities of } \\
\text { Ipomoea } \\
\text { carnea Leaves }\end{array}$ & $\begin{array}{l}\text { Antimikrobak } \\
\text { terial }\end{array}$ & daun & $\begin{array}{l}\text { Belum } \\
\text { teridentifi } \\
\text { kasi }\end{array}$ & $\begin{array}{l}\text { Daun kangkung hutan } \\
\text { diekstraksi dengan metode } \\
\text { sokhletasi, pelarut yang } \\
\text { digunakan n-heksan, etil asetat, } \\
\text { etanol, aseton dan fraksi aseton } \\
\text { dari ekstrak aseton. Lalu diuji } \\
\text { aktivitas entomologi, n-heksan } \\
\text { menunjukkan hasil yang } \\
\text { negatif, lalu diuji antibakteri } \\
\text { hanya ekstrak aseton yang } \\
\text { aktivitasnya paling besar, } \\
\text { sehingga dilanjutkan pengujian } \\
\text { antibakteri fraksi aseton. } \\
\text { Pengujian antibakteri } \\
\text { menggunakan bakteri gram } \\
\text { negatif dan positif yaitu E.coli, } \\
\text { S. aureus, S. typhimurium, } P \text {. } \\
\text { aeruginosa, P. vulgaris dan B. } \\
\text { cereus dengan metode difusi } \\
\text { cakram. Sebagai kontrol positif } \\
\text { adalah streptomisin. }\end{array}$ \\
\hline $\begin{array}{l}\text { Khalid, } \\
\text { et al, } \\
2011\end{array}$ & $\begin{array}{l}\text { Antiiflammato } \\
\text { ry activity of } \\
\text { aqueous } \\
\text { extract of } \\
\text { Ipomoea } \\
\text { carnea Jacq }\end{array}$ & antiinflamasi & daun & $\begin{array}{l}\text { Flavonol, } \\
\text { polihidrok } \\
\text { si alkaloid }\end{array}$ & $\begin{array}{l}\text { Daun kangkung hutan } \\
\text { diekstraksi dengan sokhletasi } \\
\text { menggunakan petroleum eter, } \\
\text { kloroform, etanol dan air. } \\
\text { Pengujian dilakukan dengan } \\
\text { hewan uji tikus ras Wistar. }\end{array}$ \\
\hline
\end{tabular}


Avicenna : Journal of Health Research, Vol 4 No 1. Maret 2021 (99 - 110)

Nova Rahma Widyaningrum, Andriani Noerlita Ningrum, Siti Maesaroh

(Review Aktivitas Farmakologi Tanaman Kangkung Hutan (Ipomoea Carnea Jacq))

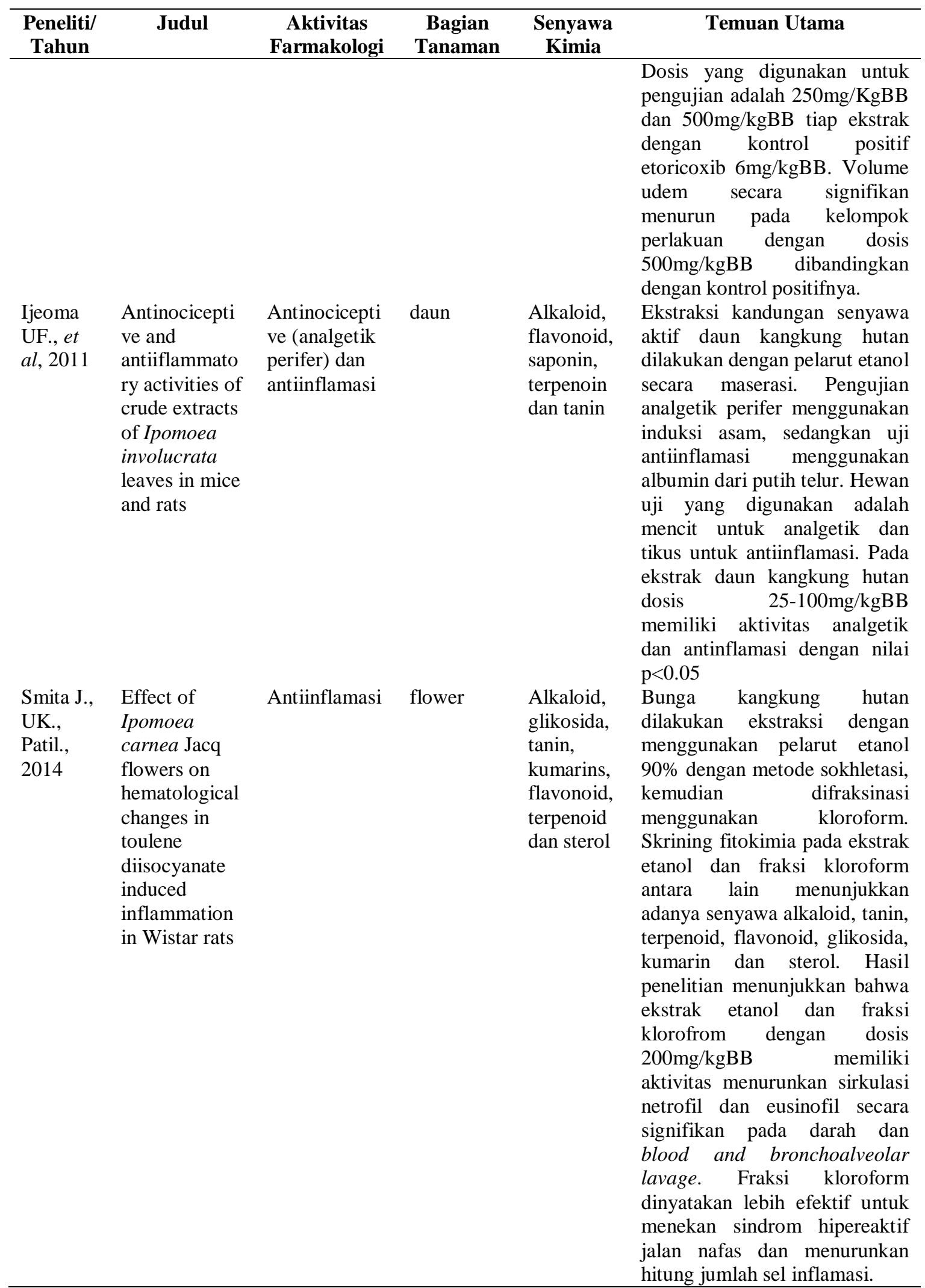




\begin{tabular}{|c|c|c|c|c|c|}
\hline $\begin{array}{c}\text { Peneliti/ } \\
\text { Tahun }\end{array}$ & Judul & $\begin{array}{c}\text { Aktivitas } \\
\text { Farmakologi } \\
\end{array}$ & $\begin{array}{c}\text { Bagian } \\
\text { Tanaman } \\
\end{array}$ & $\begin{array}{c}\text { Senyawa } \\
\text { Kimia } \\
\end{array}$ & Temuan Utama \\
\hline $\begin{array}{l}\text { Adsul } \\
\text { VB., et } \\
\text { al, } 2012\end{array}$ & $\begin{array}{l}\text { Evaluation of } \\
\text { Antioxidant } \\
\text { activity of } \\
\text { Ipomoea } \\
\text { carnea Leaves }\end{array}$ & $\begin{array}{l}\text { Antioksidan } \\
\text { dan } \\
\text { antikanker }\end{array}$ & $\begin{array}{l}\text { Daun dan } \\
\text { bunga }\end{array}$ & $\begin{array}{l}\text { Senyawa } \\
\text { fenolik } \\
\text { dan } \\
\text { flavonoid }\end{array}$ & $\begin{array}{l}\text { Senyawa fenolik dan flavonoid } \\
\text { diduga dapat menangkap } \\
\text { radikal bebas dari senyawa } \\
\text { DPPH. Ekstrak yang diuji } \\
\text { adalah ekstrak aceton, etanol } \\
\text { dan etilasetat dengan variasi } \\
\text { dosis antara } \\
\text { 500mikrogram/ml. } \\
\text { penelitian menunjukkan bahwa } \\
\text { senyawa yang terkandung pada } \\
\text { ekstrak daun dan bunga } \\
\text { kangkung hutan adalah } \\
\text { senyawa fenolik dan flavonoid. } \\
\text { Aktivitas antioksidan terbesar } \\
\text { adalah ekstrak aseton dengan } \\
\text { nilai penghambatan 25-89\%; } \\
\text { kemudian etanol sebesar 10,55- } \\
88,11 \% \text { dan etil asetat sebesar } \\
5,5-79 \% \text { dibandingkan dengan } \\
\text { antioksidan standar yaitu } \\
\text { vitamin C. }\end{array}$ \\
\hline $\begin{array}{l}\text { Khan } \\
\text { MZI., et } \\
\text { al, } 2018\end{array}$ & $\begin{array}{l}\text { Polyphenolic } \\
\text { profiling of } \\
\text { Ipomoea } \\
\text { carnea Jacq } \\
\text { by HPLC- } \\
\text { DAD and its } \\
\text { implications } \\
\text { in oxidative } \\
\text { stress and } \\
\text { cancer }\end{array}$ & $\begin{array}{l}\text { Antioksidan } \\
\text { dan } \\
\text { antikanker }\end{array}$ & $\begin{array}{l}\text { Bunga, } \\
\text { akar dan } \\
\text { daun }\end{array}$ & $\begin{array}{l}\text { Senyawa } \\
\text { fenolik } \\
\text { dan } \\
\text { flavonoid }\end{array}$ & $\begin{array}{l}\text { Total antioksidan maksimal dan } \\
\text { potensial menurunkan oksidan } \\
\text { pada ekstrak campuran metanol } \\
\text { dan air destilasi }(1: 1) \text { pada } \\
\text { bunga sebesar } 42.62 \pm 0,47 \mu \mathrm{g} \\
\text { AAE/mgDW; pada ekstrak } \\
\text { aseton dan air destilasi sebesar } \\
24,38 \pm 0,39 \mu \mathrm{g} \text { AAE/mgDW; } \\
\text { ekstrak akar etanol-kloroform } \\
\text { memiliki daya hambat tertinggi } \\
\text { dengan nilai IC } 61,22 \mu \mathrm{g} / \mathrm{ml} \\
\text { dimana } 94,64 \% \text { menunjukkan } \\
\text { aktivitas sitotoksik pada larva } \\
\text { udang. }\end{array}$ \\
\hline
\end{tabular}

\section{Pembahasan}

\section{Aktivitas Tanaman Kangkung Hutan sebagai Penyembuh Luka Sayat}

Artikel penelitian yang dilakukan oleh Ambiga, et al (2007) menggunakan bunga kangkung hutan untuk diuji farmakologinya. Bunga kangkung hutan segar, dikeringkan kemudian diekstraksi menggunakan refluk dengan pelarut etanol 95\%, kemudian difraksinasi menggunakan pelarut dietileter, kloroform dan etilasetat.

Hasil identifikasi dengan menggunakan kromatografi menunjukkan bahwa ekstrak dan fraksi bunga kangkung hutan memiliki kandungan flavonol dan kaeferol, yang keduanya termasuk golongan flavonoid. Baik metode sayatan insisi maupun eksisi, hasil pengamatan menunjukkan bahwa ekstrak bunga kangkung hutan memberikan pengaruh yang bermakna terhadap kesembuhan luka sayatan dengan pembanding kontrol positifnya. Studi histologi terhadap perbaikan luka 
sayatan menunjukkan bahwa luka yang diberi senyawa kaemferol meningkatkan secara signifikan deposit kolagen, makrofage sedikit, jaringan edema dan banyak fibroblast, hal ini hampir sama dengan yang terjadi pada kontrol positif. Sedangkan senyawa flavonol menunjukkan perubahan kolagen deposit moderat.

Artikel di atas cukup lengkap, karena tidak hanya melakukan uji aktivitas saja tetapi juga mengidentifikasi senyawa yang terkandung pada ekstrak dengan menggunakan kromatografi kolom dilengkapi dengan spektrofotometri. Senyawa yang diperoleh juga dibandingkan kekuatan aktivitasnya sebagai penyembuh luka sayat, baik luka yang dalam maupun yang hanya pada permukaan saja.

Flavonoid adalah dikenal tidak hanya mengurangi peroksidasi lipid tetapi juga dapat mencegah atau memperlambat permulaan sel nekrosis tetapi juga dengan meningkatkan vaskularisasi. Hal inilah diyakini bahwa obat apa pun yang menghambat lipid peroksidasi diyakini dapat meningkatkan viabilitas fibril kolagen dengan meningkatkan kekuatan serat kolagen, meningkatkan sirkulasi mencegah kerusakan sel dan dengan mempromosikan sintesis DNA. Flavonoid untuk mempercepat kesembuhan proses luka sayat terutama disebabkan karena zat dan kemampuan antimikroba, yang tampaknya bertanggung jawab atas kontraksi luka dan peningkatan tingkat epitelisasi. Serupa kemampuan aktivitasnya dengan Vernonia arborea dan Pentas lanceolataI.

\section{Aktivitas Tanaman Kangkung Hutan sebagai Antimikroba}

Penelitian yang dilakukan oleh Adsul VB., et al (2012) adalah melakukan pengujian aktivitas antimkroba pada ekstrak daun kangkung hutan. Senyawa yang terdapat pada daun, diekstraksi dengan metode sokhletasi menggunakan pelarut nheksana, etilasetat, aseton dan etanol. Pengujian antimikroba selanjutnya dilakukan dengan metode difusi kertas cakram dengan menggunakan 6 bakteri yang berbeda, yaitu E.coli, $S$. aureus, S. typhimurium, P. aeruginosa, P. vulgaris dan $B$. cereus. Dosis masing-masing ekstrak yang digunakan untuk pengujian adalah 200mg. Parameter yang diamati adalah kemampuan daya hambatnya yang ditunjukkan dengan zona diamater yang diukur dalam milimeter, dengan kontrol positif streptomisin dan flukonazole.

Aktivitas antibakteri ekstrak kasar daun I. carnea seperti n-heksana (1), etil asetat (2), aseton (3), etanol (4) dan fraksi aseton (fraksi A) dari ekstrak aseton. Itu ekstrak aseton mentah menunjukkan aktivitas melawan Proteus vulgaris dan Salmonella typhimurium, sedangkan etanol mentah ekstrak ellucidates aktivitas antimikroba terhadap Pseudomonous auroginosa. Ini adalah laporan pertama yang ditampilkan penghambatan Proteus vulgaris dan Salmonella typhimurium oleh ekstrak aseton sedangkan ekstrak etanol menunjukkan penghambatan yang menjanjikan terhadap Pseudomonous auroginosa daun I. Carnea.

Ekstrak aseton memiliki aktivitas antimikroba paling besar, dengan penghambatan terhadap bakteri $P$. Vulgaris $9 \mathrm{~mm}$ dan $S$. typhimurium $7 \mathrm{~mm}$. Pengujian antimikroba pada artikel ini cukup lengkap karena tidak hanya menggunakan bakteri gram negatif saja tetapi juga bakteri gram negatif, sehingga jika efektif untuk keduanya, maka ekstrak tersebut memiliki potensi antibakteri spektrum luas. Kekurangan artikel ini adalah tidak dilakukannya uji identifikasi 
senyawa yang terkandung pada tiap ekstrak yang diuji, sehingga diperlukan penelitian lanjutan mengenai senyawa aktif yang berfungsi sebagai antimikroba terutama di ekstrak aseton dan fraksinya.

\section{Aktivitas Tanaman Kangkung Hutan sebagai Analgetik dan Antiinflamasi}

Penelitian mengenai kemampuan analgetik dan antiinflamasi dari tanaman kangkung hutan diperoleh dari artikel Smita J. Dan UK Patil (2014), Ijeoma UF, et al (2011) dan Khalid, et al (2011). Ketiga artikel tersebut menggunakan bagian tanaman yang berbeda, dimana Khalid, et al (2011) dan Ijeoma UF, et al (2011) menggunakan daun sedangkan Smita (2014) menggunakan bunga. Ketiga artikel tersebut lengkap, tidak hanya melakukan pengujian aktivitas saja tetapi juga melakukan identifikasi senyawa yang terkandung pada ekstrak yang diuji. Sebagian besar ketiga artikel tersebut menyimpulkan hal yang sama, yaitu senyawa yang terkandung pada ekstrak baik daun maupun bunga kangkung hutan adalah golongan flavonoid, alkaloid dan senyawa fenolik. Penelitian yang dilakukan Ijeoma UF, et al (2011) juga dilengkapi dengan pengujian aktivitas analgetik, tidak hanya aktivitas antiinflamasi saja seperti yang dilakukan Smita dan UK Patil (2014) dan Khalid, et al (2011).

Khalid (2011) melakukan proses ekstraksi pada daun kangkung hutan menggunakan metode sokhletasi dengan beberapa pelarut berdasarkan tingkat kepolaritasan yang berbeda, yaitu petroleum eter, kloroform, etanol dan air. Namun pada artikel ini, informasi pengujian aktivitas antiinflamasi hanya pada ekstrak air saja, ekstrak etanol, petroleum eter dan kloroform tidak ada data yang lengkap. Dosis yang digunakan pada pengujian ini ada 2 , yaitu $250 \mathrm{mg} / \mathrm{kgBB}$ dan $500 \mathrm{mg} / \mathrm{kgBB}$ dimana sebelumnya telah dilakukan uji toksisitas akut terlebih dahulu. Induksi inflamasi pada artikel ini dengan menggunakan karagenin, yang diinjeksikan pada kaki tikus, sedangkan kontrol positif yang digunakan adalah etoricoxib. Pada penelitian ini dosis $500 \mathrm{mg} / \mathrm{kgBB}$ ekstrak air memberikan potensi yang besar dalam menurunkan udem di kaki tikus sebesar 39\% sedangkan kontrol positif sendiri juga 39\%. Ekstrak daun kangkung hutan dapat menghambat paling tidak satu dari enzim-enzim yang terlibat dalam peristiwa terjadinya inflamasi, enzim tersebut antara lain enzim sikooksigenasi 1, siklooksigenasi 2, pospolipid 2, lipooksigenase 5 dan lipooksigenasi 1-2. Hal ini juga diperkuat dengan penggunaan dosis ekstrak yang digunakan, dan pada artikel ini dosis yang memiliki kemampuan besar sebagai antiinflamasi adalah dosis $500 \mathrm{mg} / \mathrm{kgBB}$.

Smita dan UK Patil (2014) melakukan penyarian bunga kangkung hutan menggunakan sokhletasi dengan pelarut etanol $90 \%$ diperoleh rendemen 6,89\%, kemudian larutan yang bebas alkohol difraksinasi menggunakan kloroform, sehingga diperoleh ekstrak etanol dan fraksi kloroform. Dilanjutkan dengan pengujian fitokimia, diperoleh hasil screening bahwa senyawa yang terkandung pada ekstrak etanol dan fraksi kloroform adalah alkaloid, glikosida, tanin, kumarin, flavonoid, terpenoid dan sterol. Dosis yang digunakan adalah $100 \mathrm{mg} / \mathrm{kgBB}$ dan 200mg/kgBB, dengan kontrol positif deksametason. Pengamatan dilakukan dengan mengamati perubahan pada sel-sel darah yang berperan dalam proses peradangan dan inflamasi seperti eusinofil, basofil, 
limfosit, monosit, neutrofil, total sel dan suhu tubuh juga bronchoalveolar lavage (BAL).

Pada artikel ini menganalisis dan menguji kemampuan antiinflamasi dan antialergi pada penderita asma, sehingga induksi yang dilakukan pada hewan uji menggunakan toluen diisosianat, dimana senyawa ini sensitif dan dapat menimbulkan asma. Kejadian inflamasi dan peradangan dilihat dari perubahan sel-sel yang terkait baik pada sel darah maupun sel bronchoalveolar. Hasil penelitian Smita (2014) menunjukkan bahwa ekstrak etanol dan fraksi kloroform dengan dosus $200 \mathrm{mg} / \mathrm{kgBB}$ dapat menurunkan sel yang berperan pada proses inflamasi. Golongan senyawa aktif yang memiliki potensi tersebut adalah stigmasterol. Hasil penelitian menunjukkan bahwa ekstrak etanol dan fraksi klorofrom dengan dosis $200 \mathrm{mg} / \mathrm{kgBB}$ memiliki aktivitas menurunkan sirkulasi netrofil dan eusinofil secara signifikan pada darah dan blood and bronchoalveolar lavage. Fraksi kloroform dinyatakan lebih efektif untuk menekan sindrom hipereaktif jalan nafas dan menurunkan hitung jumlah sel inflamasi.

Pada artikel penelitian yang dilakukan oleh Ijeoma UF, et al (2011) melakukan penyarian daun kangkung hutan menggunakan metode maserasi selama 5 hari dengan pelarut etanol. Hewan uji yang digunakan adalah tikus dan mencit, hanya saja tidak diinformasikan ras yang digunakan. Pengujian aktivitas analgetik menggunakan induksi asam asetat, sedangkan pengujian antiinflamasi menggunakan induksi albumin putih telur. Hasil skrining fitokimia hampir sama, yaitu pada ekstrak etanol terkandung senyawa kimia flavonoid, terpenoid, saponin, tanin dan alkaloid. Pengujian menggunakan dosis ekstrak antara $25-$ $100 \mathrm{mg} / \mathrm{kgBB}$.

Flavonoid memiliki khasiat sebagai antiinflamasi maupun analgetik dengan mekanisme kerja menghambat enzim yang menginisiasi mediator nyeri dan inflamasi. Flavonoid juga mampu menghambat prostaglandin dimana senyawa ini mampu menyebabkan nyeri dan inflamasi (Saleem, et al, 2011). Efek analgesik dari Ipomoea involucrata dapat dikaitkan sebagian dengan efek anti-inflamasi seperti dalam model nyeri visceral. Prekursor melepaskan arakidonik asam melalui biosintesis sikloigenase dan prostaglandin yang berperan dalam mekanisme nosiseptif (Uche, et al, 2009). Upaya ini berimplikasi pada penghambatan inflamasi akut oleh ekstrak yang menghambat proses terjadinya nyeri.

\section{Aktivitas Tanaman Kangkung Hutan sebagai Antioksidan dan Antikanker}

Penelitian yang dilakukan oleh Adsul (2012) dan Khan (2018) mengenai aktivitas antioksidan dan antikanker daun, bunga dan akar dari tanaman kangkung hutan. Adsul (2012) menyatakan bahwa Senyawa fenolik dan flavonoid diduga dapat menangkap radikal bebas dari senyawa DPPH. Ekstrak yang diuji adalah ekstrak aceton, etanol dan etilasetat dengan variasi dosis antara 50$500 \mathrm{mikrogram} / \mathrm{ml}$. Hasil penelitian menunjukkan bahwa senyawa yang terkandung pada ekstrak daun dan bunga kangkung hutan adalah senyawa fenolik dan flavonoid. 
Aktivitas antioksidan terbesar adalah ekstrak aseton dengan nilai penghambatan 25-89\%; kemudian etanol sebesar $10,55-88,11 \%$ dan etil asetat sebesar 5,5-79\% dibandingkan dengan antioksidan standar yaitu vitamin C. Sedangkan Khan (2018) menyatakan bahwa Total antioksidan maksimal dan potensial menurunkan oksidan pada ekstrak campuran metanol dan air destilasi (1:1) pada bunga sebesar $42.62 \pm 0,47 \mu \mathrm{g}$ AAE/mgDW; pada ekstrak aseton dan air destilasi sebesar 24,38 $\pm 0,39 \mu \mathrm{g}$ AAE/mgDW; ekstrak akar etanol-kloroform memiliki daya hambat tertinggi dengan nilai $\mathrm{IC}_{50} 61,22 \mu \mathrm{g} / \mathrm{ml}$ dimana $94,64 \%$ menunjukkan aktivitas sitotoksik pada larva udang.

\section{SIMPULAN DAN SARAN}

\section{Simpulan}

Adapun simpulan dari kajian literatur review mengenai aktivitas farmakologi tanaman kangkung hutan adalah tanaman kangkung hutan memiliki aktivitas mempercepat kesembuhan luka sayat, antimikroba, antiinflamasi, analgetik, antioksidan dan antikanker. Hal ini sejalan dengan kandungan senyawa aktif baik pada ekstrak daun, bunga akar adalah flavonoid, tanin, alkaloid, kumarin, senyawa fenolik, saponin dan sterol. Senyawa aktif yang terkandung pada ekstrak memiliki mekanisme kerja yang beragam sesuai dengan kontrol positif yang digunakan pada pengujian aktivitas farmakologinya.

\section{Saran}

Penelitian lanjutan dapat meneliti tentang uji aktivitas antipiretiknya baik dengan senyawa polar, semipolar maupun nonpolar dari ekstrak kangkung hutan. Penelitian lanjutan dapat dilakukan dengan mengidentifikasi senyawa aktif yang berperan pada kemampuan antipiretiknya. Perlu dilakukan review dengan membatasi baik metode pengujian, pelarut, maupun uji aktivitas farmakologinya.

\section{DAFTAR PUSTAKA}

Abbasi MA., Zafar A., Riaz T., Rehman A., Arshad S., Shahwar D., et al, 2010, Evaluation of Comparative Antioxidant Potential of Aqueous and Organic Fractions of Ipomoea carnea, Journal of Medicinal Plants Research Vol 4 (18), 1883-1887

Adsul VB, et al, 2012, Antimicrobial Activities of Ipomea carnea Leaves, J. Nat. Prod. Plant Resour, 2(5):597-600

Deshpande NR, et al, 2012, Evaluation of Antioxidant activity of Ipomea carnea Leaves, J. Nat. Prod. Plant Resour, 2(5):584-588

Freddy IW., 2007, Analgesik, antipiretik, antiinflamasi non steroid dan obat pirai; Farmakologi dan Terapi Edisi 5, Fakultas Kedokteran UI; Jakarta

Gunawan, 2007, Farmakologi dan Terapi Edisi Kelima, UI Press; Jakarta

Jeffrey AG., 1994, Demam, Termasuk Demam yang Tidak Diketahui Penyebabnya, Prinsip-Prinsip Ilmu Penyakit Dalam Harrison, Penerbit Buku Kedokteran EGC; Jakarta 
Khalid S, et al, 2011, Antiinflamatory Activity of Aqueous Extract of Ipomea carnea Jacq, Pharmacologyonline:326-331

Khatiwora E, et al, 2010, Spectroscopic determination of total phenol and flavonoid contents of Ipomea carnea, International Journal of ChemTech Research, Vol 2, No. 3, 1698-1701

Moot CL, Bodhi W dan Mongi J, 2013, Uji Efek Antipiretik Infusa Daun Sesewanu (Clerodendron squamatum Vahl.) Terhadap Kelinci Jantan Yang Diinduksi Vaksin DTP-HB, Jurnal Ilmiah Farmasi-Pharmacon Vol. 2 No. 03, Program Studi Farmasi UNSRAT; Manado

Robinson T., 1991, Kandungan Organik Tumbuhan Tinggi Edisi 6, Penerbit ITB; Bandung

Saleem TKM, Azeem AK, Dilip C, Sankar C, Prasanth NV, Duraisami R. Anti inflammatory activity of the leaf extracts of Gendarussa vulgaris Nees. Asia Pac J Trop Biomed 2011;1(2):147-9.

Sarma A., and Bachheti RK., 2013, A Review on Ipomoea carnea, Iternational Journal of Pharma and Biosciences, 4(4):(P) 363-377

Tjay TH., dan Rahardja K., 2013. Obat-Obat Penting, Khasiat, Penggunaan dan Efek Samping Edisi Ke-6, PT. Elex Media Komputindo; Jakarta

Tjay TH., dan Rahardja K., 2015, Obat-obat Penting, Khasiat, Penggunaan dan Efek-efek Sampingnya, Edisi Ke-7, Jakarta; PT. Elex Media Komputindo

Uche FI, Okunna BU. Phytochemical constituents, analgesic and anti inflammatory effects of methanol extract of Triumfetta rhomboidea leaf extract in animal models. Asian Pac J Trop Med 2009:2 (5): 26-33

Widyaningrum, N.R., Parmadi, A., Wicaksono, W., 2016. Profil Kromatografi Lapis Tipis Ekstrak Etanol Daun Talok (Muntingia Calabura L) Beserta Potensinya Sebagai Pereda Nyeri, IJMS, Vol 3 No 1

Wilmana F., 2007, Analgesik-Antipiretik (Analgesik Antiinflamasi Nonsteroid dan Obat Pirai), Farmakologi dan Terapi Edisi 4, Bagian Farmakologi Kedokteran Universitas Indonesia; Jakarta 